\title{
HUBUNGAN ANTARA PERSEPSI PESERTA DIKLAT TENTANG PENGGUNAAN MEDIA ANIMASI KOMPUTER DAN MOTIVASI BELAJAR DENGAN HASIL BELAJAR INSEMINASI BUATAN (IB) DI BBPKH CINAGARA BOGOR
}

\author{
Taufik Walhidayah \\ Program Studi Teknologi Pendidikan \\ Sekolah Pascasarjana Universitas Ibn Khaldun Bogor \\ Jl. KH. Sholeh Iskandar KM. 2 Kd. Badak, Kota Bogor \\ taufik.cinagara@gmail.com
}

\begin{abstract}
Abstrak: Tujuan penelitian ini adalah Hubungan antara persepsi peserta diklat tentang media animasi komputer dan motivasi belajar secara bersama-sama dengan hasil belajar Inseminasi buatan di BBPKH Cinagara Bogor. Populasi target dari penelitian ini adalah seluruh Peserta diklat /penyuluh di BBPKH Cinagara Bogor yang berjumlah 30 orang. Sedangkan populasi terjangkau adalah Peserta diklat yang berjumlah 30 orang. Hasil penelitian disimpulkan sebagai berikut : (1) Terdapat hubungan positif dan signifikan antara persepsi peserta diklat tentang media animasi komputer dengan hasil belajar inseminasi buatan di BBPKH Cinagara Bogor. Koefisien determinan R Square (r2y1) sebesar 0.294 yang berarti faktor media animasi komputer (X1) berperan atau memberikan kontribusi sebesar 29.4\% dengan Hasil belajar inseminasi buatan (Y) sedangkan sisanya 70.6 \% Hasil belajar inseminasi buatan dipengaruhi oleh faktor lain.(2) Terdapat hubungan positif dan signifikan motivasi belajar dengan hasil belajar Inseminasi buatan di BBPKH Cinagara Bogor teruji kebenaranya. Koefisien determinan R Square (r2y1) sebesar 0.601 yang berarti faktor motivasi belajar (X2) berperan atau memberikan kontribusi sebesar $60.1 \%$ dengan Hasil belajar inseminasi buatan (Y) sedangkan sisanya 39.9\% Hasil belajar inseminasi buatan dipengaruhi oleh faktor lain.(3) Terdapat hubungan positif dan signifikan antara persepsi peserta diklat tentang media animasi komputer dan motivasi belajar secara bersama-sama dengan hasil belajar Inseminasi buatan di BBPKH Cinagara Bogor. Nilai koefisien determinan (r2y.12) sebesar 0.602 yang berarti faktor media animasi komputer (X1) dan Motivasi belajar (X2) secara bersama-sama berperan/memberikan kontribusi sebesar $60.2 \%$. Sisanya $39.8 \%$ Hasil belajar inseminasi buatan dipengaruhi oleh faktor lain (Y)..
\end{abstract}

Kata Kunci: Persepsi Peserta Diklat Tentang Media Animasi Komputer, Motivasi Belajar, Hasil Belajar Inseminasi Buatan.

\section{PENDAHULUAN}

Pertambahan

permintaan

masyarakat terhadap produk peternakan terutama daging dipengaruhi oleh meningkatnya jumlah penduduk, disamping itu pertambahan pendapatan dan tumbuhnya kesadaran masyarakat akan pentingnya mengkonsumsi makanan bergizi juga menambah tingginya permintaan akan daging. Permintaan yang tinggi ini seharusnya diimbangi dengan pertambahan jumlah 
populasi sapi sebagai ternak penghasil daging. Untuk meningkatkan populasi ternak, Pemerintah telah melakukan berbagai program bioteknologi reproduksi yaitu inseminasi buatan (IB). Program IB merupakan cara yang efektif dan pernah diciptakan oleh manusia guna meningkatkan populasi dan produksi ternak secara kuantitatif maupun kualitatif.

Peternakan sapi potong di Indonesia secara umum masih merupakan usaha peternak dalam skala kecil sebagai usaha sampingan dan bersifat tradisional. Pemeliharaan secara tradisional tersebut mengakibatkan produktivitas yang dihasilkan kurang optimal sehingga perlu dilakukan pengembangan. Pengembangan ternak sapi potong tidak lepas dari tantangan berupa pengadaan bibit. Pengadaan bibit sapi potong yang secara kuantitatif masih rendah sehingga pemerintah mengeluarkan salah satu program nasional adalah program pembinaan mutu bibit. Pemerintah akan melakukan kegiatan tersebut diantaranya adalah penyebaran pejantan unggul dan meningkatkan program inseminasi buatan dengan didampingi tenaga penyuluh yang profesional .
Pola pembibitan yang lebih terpadu harus segera dilakukan secara sistematis. Peran pemerintah masih sangat diperlukan dalam era otonomi daerah. Tantangan untuk dapat mendesain pola pembibitan yang terpadu akan sedikit mengalami kesulitan dalam aspek pola pembinaan oleh Dinas Peternakan atau lembaga terkait. Pola pembibitan bersifat lintas sektoral dan melibatkan berbagai aspek kepentingan sosial dan ekonomi yang dalam batas-batas tertentu tidak dapat dikendalikan oleh unsur birokrasi yang dalam praktek sangat dibatasi oleh tugas dan wewenang administratif daerah. Menyadari kekurangan tersebut, berbagai langkah kebijakan telah ditempuh oleh Pemerintah antara lain melalui pengembangbiakan ternak dengan bantuan inovasi baru seperti teknologi inseminasi buatan. (Pateda, 2010:6)

Inseminasi buatan merupakan salah satu teknologi dalam reproduksi ternak yang memiliki manfaat dalam mempercepat peningkatan mutu genetik ternak, mencegah penyebaran penyakit reproduksi yang ditularkan melalui perkawinan alam, meningkatkan efisiensi penggunaan pejantan unggul, serta menurunkan atau 
menghilangkan biaya investasi Anggapan dimasyarakat perkawinan pengadaan dan pemeliharaan ternak dengan inseminasi buatan merupakan pejantan inseminasi buatan. beban masih kuat karena harus (Sugeng, 1997:23)

Namun berhasil tidaknya mengeluarkan sejumlah uang menjadi pengembangan teknologi ditentukan salah satu penghambat dalam oleh kemampuan petugas dalam peningkatan jumlah populasi sapi di mengadopsi teknologi yang dianjurkan. masyarakat. Hal tersebut menjadi Keputusan mengadopsi suatu teknologi banyak dipengaruhi sifat teknologi.

Parameter keberhasilan teknologi IB di lapangan adalah nilai Service per Conception atau S/C. Nilai S/C adalah jumlah IB yang dilakukan (service) untuk menghasilkan satu kebuntingan (conception), selain itu keberhasilan IB juga ditentukan oleh sistem pencatatan (recording) terhadap aktivitas reproduksi ternak untuk mendukung manajemen perkawinan yang baik

Menurut Demita $\quad(2011 ; 87)$ perhatian semua pihak khususnya di BBPKH Cinagara Bogor. Pihak BBPKH Cinagara menjadi bagian penting dalam memberikan edukasi berupa pemberian pengetahuan dan pelatihan guna meningkatkan profesionalisme petugas inseminator dengan usaha peningkatan kapasitas melalui Program inseminasi buatan yang merupakan salah satu upaya penerapan teknologi tepat guna yang merupakan pilihan utama untuk peningkatan populasi dan mutu genetik. Bahwa tingkat keberhasilan IB meskipun nilai manfaat inseminasi buatan telah terbukti, namun upaya memaksimalkan inovasi tersebut masih terkendala oleh beberapa faktor antara lain: - Terbatasnya pelayanan yang disediakan (SDM dan fasilitas) - Jumlah akseptor relatif kecil - Petugas inseminator belum mampu menjadi agen pembaharu peternakan sapi potong. - Pola pemeliharaan sebagian besar masih semi intensif. sangat dipengaruhi oleh empat faktor yang saling berhubungan yaitu pemilihan sapi akseptor, pengujian kualitas semen, akurasi deteksi birahi oleh para peternak dan keterampilan inseminator. Tetapi pada penelitian ini yang akan dibahas adalah peningkatan kapasitan dan pengetahuan petugas inseminator melalui pemberian diklat dengan pendekatan media pembelajaran animasi komputer, 
dengan maksud agar materi mudah dipahami dengan mudah oleh peserta diklat/ petugas inseminator dengan mempertimbangkan Karakteristik peserta diklat/ petugas inseminator ialah motivasi peserta diklat/ petugas inseminator yang menjadi salah satu dasar peningkatan pemahaman tentang inseminasi buatan. Karakteristik peserta diklat/ petugas inseminator dapat berupa pengetahuan, motivasi. Pengetahuan yang tinggi, maka peserta diklat/ petugas inseminator akan mudah mengadopsi inovasi baru.

Hal ini sesuai dengan pendapat Mardikanto (1993:12) bahwa semakin tinggi tingkat pengetahuan, maka semakin mudah melakukan adopsi terhadap inovasi baru. Kurangnya pengetahuan menyebabkan rendahnya tingkat produktivitas serta membatasi untuk mengadakan inovasi baru. Motivasi yang tinggi akan berpengaruh terhadap adopsi teknologi inseminasi buatan.

\section{METODOLOGI}

\section{A. Tujuan Penelitian}

tujuan dari penelitian ini yaitu untuk menguji:

1) Hubungan antara persepsi peserta diklat tentang media animasi komputer dengan hasil belajar inseminasi buatan di BBPKH Cinagara Bogor.

2) Hubungan antara motivasi belajar dengan hasil belajar Inseminasi buatan di BBPKH Cinagara Bogor.

3) Hubungan antara persepsi peserta diklat tentang media animasi komputer dan motivasi belajar secara bersama-sama dengan hasil belajar Inseminasi buatan di BBPKH Cinagara Bogor.

\section{B. Tempat dan Waktu Penelitian}

Penelitian ini mengambil lokasi di BBPKH Cinagara Bogor. Penelitian berlangsung 4 (empat) bulan.

\section{Metoda Penelitian}

Metoda yang digunakan adalah metoda survey dengan pendekatan korelasional. Kegiatan penelitian ini dapat dikatakan merupakan upaya untuk menggambarkan variabel yang menyangkut hubungan yang berkaitan dengan hasilbelajar di BBPKH Cinagara Bogor.

Metoda pengumpulan data untuk mendapatkan data primer di lapangan dengan menggunakan angket dalam bentuk kuisioner. Dalam kuisioner 
tersebut tersusun beberapa butir

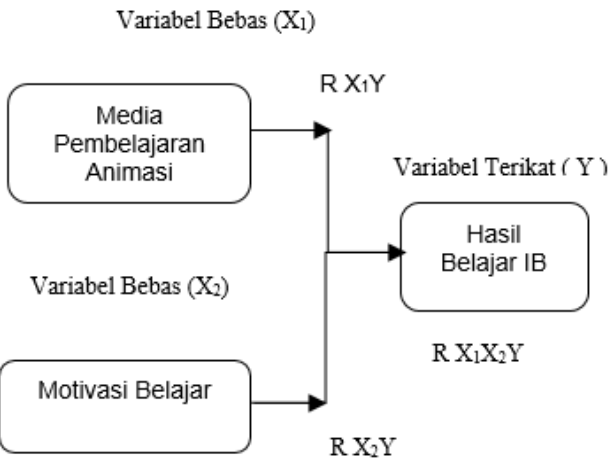

Cinagara Bogor, sedangkan responden terdiri Peserta Diklat, pimpinan BBPKH Cinagara dan Widyaiswara di

Gambar 1. Konstelasi Variabel Penelitian BBPKH Cinagara Bogor.

Pada penelitian ini terdapat variable terikat yaitu Hasil Belajar (Y) dan dua variable bebas yaitu Pemanfaatan Media pembelajaran Animasi Komputer (X1) dan Motivasi (X2).

Maka konstelasi hubungan antara ketiga variable tersebut yaitu, media animasi komputer (X1) motivasi Belajar (X2) sebagai variable bebas, sedangkan hasil belajar IB (Y). Sebagai variable terikat, sehingga diduga hubungan antara X1 dan X2 bersama sama terhadap $\mathrm{Y}$ dapat divisualisasi Gambar 1 berikut.

\section{Populasi dan Sampling}

1) Populasi Penelitian

Populasi target dari penelitian ini adalah seluruh Peserta diklat /penyuluh di BBPKH Cinagara Bogor yang berjumlah 30 orang. Sedangkan populasi terjangkau adalah Peserta diklat yang berjumlah 30 orang.

Tabel 1. Jumlah Polulasi Penelitian

\begin{tabular}{|c|c|c|c|c|}
\hline No & $\begin{array}{c}\text { Jenis } \\
\text { Polulasi }\end{array}$ & L & P & Jumlah \\
\hline 1 & Target & 28 & 2 & 30 \\
\hline 2 & Terjangkau & 28 & 2 & 30 \\
\hline
\end{tabular}

2) Teknik pengambilan sampel.

Dari populasi terjangkau 30 orang, maka teknik penentuan sampel dilakukan dengan menggunakan teknik sensus. Dengan demikian dari jumlah populasi terjangkau sebanyak 30 orang, maka jumlah sampelnya 30 orang. Uji coba instrumen dilaksanakan di BBPKH Cinagara Bogor dengan 
responden berjumlah 20 orang Peserta diklat.

\section{E. Hasil Uji coba Instrumen Hasil Belajar IB}

1) Pengujian Validitas

Untuk instrumen terhadap hasil belajar Inseminasi Buatan, disusun dalam bentuk tes pilihan ganda dengan dua pilihan jawaban maka perhitungan validitas dan realibilitas dilakukan dengan langkah-langkah berikut Kelayakan instrumen penelitian dapat diungkap melalul perhitungan validitas, yaitu nilai yang menyatakan kemampuan atau kesahihan alat ukur yang digunakan dalam penelitian.

Berdasarkan skor yang diperoleh untuk tes Hasil Belajar IB, dimana jawaban berada di interval 0 (untuk jawaban yang salah) dan I (untuk jawaban yang benar), maka uji validitas butir dilakukan dengan mengunakan korelasi Point Biserial .

$$
r_{p b i}=\frac{M_{p}-M_{q}}{S_{t}} \sqrt{p q}
$$

$\mathrm{r}_{\mathrm{pbis}}=$ Koefisien korelasi point biserial

$\mathrm{M}_{\mathrm{p}} \quad$ = Jumlah responden yang menjawab benar

$\mathrm{M}_{\mathrm{q}} \quad$ = Jumlah responden yang menjawab salah

$\mathrm{S}_{\mathrm{t}} \quad=$ Standar deviasi untuk semua item

$\mathrm{p} \quad=$ Proporsi responden yang menjawab benar $\mathrm{q}=$ = Proporsi responden yang menjawab benar

Untuk $r_{\text {pbis }}$ yang didapat selanjutnya dikonsultasikan pada nilai product moment, untuk jumlah responden 20 orang dengan derajat kepercayaan diri $1 \%$. Selanjutnya jika $r_{\text {pbis }}>r$ tabel maka item soal tersebut valid.

Berdasarkan data diatas, dari 30 butir soal yang di uji, terdapat soal yang Invalid. Adapun soal yang invalid ialah No: 4, 12, 14, 24, 29 (5 butir Soal). sisanya 25 butir soal dinyatakan Valid

\section{1) Uji Realibilitas Instrumen}

Butir pertanyaan yang valid yang berasal dan uji validitas selanjutnya diuji reliabilitasnya. Uji reliabilitas ini untuk menguatkan apakah instrumen layak atau tidak untuk digunakan dalam penelitian Uji reliabilitas dilakukan dengan rumus KR 20 Alpha Cronbach, yang diformulasikan sebagai berikut :

$$
\begin{aligned}
{ }_{11} & =\left[\frac{\mathrm{k}}{(\mathrm{k}-1)}\right]\left[\frac{1-\Sigma \sigma_{\mathrm{b}}{ }^{2}}{\sigma_{\mathrm{t}}{ }^{2}}\right] \\
{ }_{11} & =\text { reliabilitas instrumen } \\
\mathrm{k} & =\text { banyaknya butir pertanyaan } \\
\Sigma \sigma_{\mathrm{b}}{ }^{2} & =\text { jumlah varians butir } \\
\sigma_{\mathrm{t}}{ }^{2} & =\text { varian total }
\end{aligned}
$$


Hasil perhitugan uji reliabilitas karena $\mathrm{r}$ hitung. (0.962) lebih besar dari pada $r_{\text {tabel }}$ (0.561). dengan demikian dapat disimpulan bahwa angket penelitian Reliabel.

\section{F. Hasil Uji coba Instrumen Media Animasi Komputer}

1) Pengujian Validitas

Untuk instrumen terhadap media pembelajaran Animasi Komputer, disusun dalam bentuk tes dengan empat pilihan jawaban maka perhitungan validitas dan Realibilitas dilakukan dengan langkah-langkah berikut Kelayakan instrumen penelitian dapat diungkap melalul perhitungan validitas, yaitu nilai yang menyatakan kemampuan atau kesahihan alat ukur yang digunakan dalam penelitian.

Berdasarkan skor yang diperoleh untuk tes media pembelajaran Animasi Komputer, maka uji validitas butir dilakukan melalui rumus korelasi dengan mengunakan uji korelasi

Product Moment dengan menggunakan Statistical Package for the Sosial Sciences (SPSS). Pernyataan yang valid apabila memiliki $r_{\text {hitung }}>r_{\text {tabel }}$ pada tarap kepercayaan $\alpha ; 0.01$.

Berdasarkan data diatas, dari 30 butir soal yang di uji, terdapat soal yang Invalid. Adapun soal yang invalid ialah
No: 1, 6, 11, 16, 24 (5 butir). sisanya 25

butir soal dinyatakan Valid

2) Uji Realibilitas Instrumen

Butir pertanyaan yang valid yang berasal dan uji validitas selanjutnya diuji reliabilitasnya. Uji reliabilitas ini untuk menguatkan apakah instrumen layak atau tidak untuk digunakan dalam penelitian Uji reliabilitas dilakukan dengan rumus Alpha Cronbach.

Hasil perhitugan uji Realibilitas $\mathrm{r}_{\text {hitung. }}(0.979)$ lebih besar dari pada $\mathrm{r}_{\text {table }}$ (0.561). dengan demikian dapat disimpulan bahwa angket penelitian Reliabel.

\section{G. Hasil Uji coba Instrumen Motivasi}

1) Pengujian Validitas

Untuk instrumen terhadap Motivasi, disusun dalam bentuk tes dengan empat pilihan jawaban maka perhitungan validitas dan Realibilitas dilakukan dengan langkah-langkah berikut Kelayakan instrumen penelitian dapat diungkap melalul perhitungan validitas, yaitu nilai yang menyatakan kemampuan atau kesahihan alat ukur yang digunakan dalam penelitian.

Berdasarkan skor yang diperoleh untuk Motivasi, maka uji validitas butir dilakukan melalui rumus korelasi dengan mengunakan uji korelasi 
Product Moment dengan menggunakan Statistical Package for the Sosial Sciences (SPSS).

$\mathrm{r}_{y x}=\frac{\pi \Sigma \mathrm{X} 1 \Upsilon 1-(\Sigma \mathrm{X} 1)(\Sigma \Upsilon 1)}{\left.\sqrt{\left\{\pi \Sigma X_{12}\right.}-\left(\Sigma \mathrm{X}_{1}\right)^{2}\right\}\left\{\pi \Sigma \Upsilon_{1} 2-\left(\Upsilon_{1}\right)^{2}\right\}}$

Validitas butir instrumen tes didasarkan atas uji korelasi Product Moment yaitu korelasi antara skor butir instrumen dengan skor total seluruh butir instrumen yang bersangkutan. Pernyataan yang valid apabila memiliki $r_{\text {hitung }}>r_{\text {tabel }}$ pada tarap kepercayaan $\alpha=$ 0.01 .

Berdasarkan data diatas, dari 30 butir soal yang di uji, terdapat soal yang Invalid. Adapun soal yang invalid ialah No: 4,9,14,19,30 (5 butir). Sisanya 25 butir soal dinyatakan Valid.

2) Uji Realibilitas Instrumen

Butir pertanyaan yang valid yang berasal dan uji validitas selanjutnya diuji reliabilitasnya. Uji reliabilitas ini untuk menguatkan apakah instrumen layak atau tidak untuk digunakan dalam penelitian Uji reliabilitas dilakukan dengan rumus Alpha Cronbach.

Berdasarkan hasil perhitungan instrumen penelitian dikatakan Reliabel, karena $r$ hitung. (0.955) lebih besar dari pada $r$ table (0.561). dengan demikian dapat disimpulan bahwa angket penelitian Reliabel.

\section{HASIL PENELITIAN DAN PEMBAHASAN}

A. Uji Normalitas

1) Uji Normalitas Galat Taksiran Regresi Y Atas X1 (Hasil Belajar Inseminasi Buatan Atas Media Animasi Komputer (X1) Uji Normalitas dilakukan dengan cara sebagai berikut: (1) mencari Regresi $\mathrm{Y}$ atas $\mathrm{X}_{1}$. Mencari nilai galat taksiran. Berdasarkan hasil perhitungan, persamaan regresi $\hat{\mathrm{Y}}=$ $13.679+0.092 \mathrm{X}_{1}$. berdasarkan hasil perhitungan nilai penyimpangan maximum $=0.092$.

Selanjutnya dari daftar tabel kritis Kolmogorof- Smirnov, diperoleh nilai kritis untuk $\mathrm{n}=30$ dengan tingkat kepercayaan $\alpha=0,05$ adalah sebesar 0,224 Sedangkan untuk tingkat kepercayaan $\mathrm{a}=0,01$ sebesar 0,290.

Dengan demikian nilai perhitungan < nilai kritis $(0.102<$ 0.290). Kesimpulan data variabel Hasil belajar inseminasi buatan atas Media animasi komputer dinyatakan dari data yang berdistribusi normal. 
2) Uji Normalitas Galat Taksiran Regresi Y Atas X2 (Hasil Belajar Inseminasi Buatan Atas Motivasi Belajar (X2)

Uji Normalitas dilakukan dengan cara sebagai berikut: (1) mencari Regresi $\mathrm{Y}$ atas $\mathrm{X}_{2}$. Mencari nilai galat taksiran. Berdasarkan hasil perhitungan, persamaan regresi $\hat{\mathrm{Y}}=$ $5.491+0.195 \mathrm{X}_{2}$. berdasarkan hasil perhitungan nilai penyimpangan maximum $=0.195$

Selanjutnya dari daftar tabel kritis Kolmogorof- Smirnov, diperoleh nilai kritis untuk $\mathrm{n}=30$ dengan tingkat kepercayaan $\alpha=0,05$ adalah sebesar 0,224 Sedangkan untuk tingkat kepercayaan a =0,01 sebesar 0,290.

Dengan demikian nilai perhitungan < nilai kritis $(0.152<$ 0.290). Kesimpulan data variabel Hasil belajar inseminasi buatan atas Motivasi belajar dinyatakan dari data yang berdistribusi normal.

Tabel 2. Rangkuman Hasil Uji Normalitas Data

\begin{tabular}{|c|c|c|c|c|c|c|}
\hline \multirow[t]{2}{*}{$\begin{array}{l}\mathbf{N} \\
\mathbf{o}\end{array}$} & \multirow{2}{*}{$\begin{array}{c}\text { Galat } \\
\text { taksir } \\
\text { an }\end{array}$} & \multirow[t]{2}{*}{$\mathbf{N}$} & \multirow{2}{*}{$\begin{array}{c}\text { Nilai } \\
\text { Absolu } \\
\text { te }\end{array}$} & \multicolumn{2}{|c|}{$\begin{array}{c}\text { Nilai Tabel } \\
\text { KS }\end{array}$} & \multirow[t]{2}{*}{$\begin{array}{c}\text { Kesimpul } \\
\text { an }\end{array}$} \\
\hline & & & & $\begin{array}{c}\boldsymbol{\alpha} \\
=\mathbf{0 , 0} \\
\mathbf{5}\end{array}$ & $\begin{array}{c}\boldsymbol{\alpha} \\
=\mathbf{0 , 0} \\
\mathbf{1}\end{array}$ & \\
\hline 1 & $\begin{array}{l}\mathrm{Y} \text { atas } \\
\mathrm{X}_{1}\end{array}$ & $\begin{array}{l}3 \\
0\end{array}$ & 0.102 & $\begin{array}{c}0,22 \\
4\end{array}$ & $\begin{array}{c}0,29 \\
0\end{array}$ & $\begin{array}{l}0.102< \\
0,224 \\
0.102<0,2 \\
90 \\
\text { Berdistrib } \\
\text { usi } \\
\text { Normal }\end{array}$ \\
\hline 2 & $\begin{array}{l}\mathrm{Y} \text { atas } \\
\mathrm{X}_{2}\end{array}$ & $\begin{array}{l}3 \\
0\end{array}$ & 0.152 & $\begin{array}{c}0,22 \\
4\end{array}$ & $\begin{array}{c}0,29 \\
0\end{array}$ & $\begin{array}{l}0.152< \\
0,224 \\
0.152< \\
0,290 \\
\text { Berdistrib } \\
\text { usi } \\
\text { Normal }\end{array}$ \\
\hline
\end{tabular}

\section{B. Uji Homogenitas}

\section{1) Uji Homogenitas Hasil Belajar} Inseminasi Buatan (Y) Atas Media Animasi Komputer (X1)

Berdasarkan output SPSS di atas diketahui bahwa nilai signifikasi variabel Hasil belajar inseminasi buatan (Y) berdasarkan variabel Media animasi komputer $\left(\mathrm{X}_{1}\right)=0.286<2,64$, artinya data variabel Hasil belajar inseminasi buatan berdasarkan Media animasi komputer $\left(\mathrm{X}_{1}\right)$ berasal dari populasi yang sama (homogen).

\section{2) Uji Homogenitas Hasil Belajar} (Y) Atas Motivasi Belajar (X2) (X2)

Berdasarkan output SPSS di atas diketahui bahwa nilai signifikasi variabel Hasil belajar inseminasi buatan (Y) berdasarkan variabel Motivasi belajar $\left(\mathrm{X}_{2}\right)=0.153<2.64$, artinya data variabel Hasil belajar inseminasi buatan berdasarkan Motivasi belajar $\left(\mathrm{X}_{2}\right)$ berasal dari populasi yang sama (homogen).

Tabel 3. Rangkuman Hasil Uji Homogenitas

\begin{tabular}{|l|l|c|c|l|}
\hline No & Variabel & Sig & Asymp.Sig & Kesimpulan \\
\hline 1 & $\mathrm{Y}_{\text {atas }} \mathrm{X}_{1}$ & 0.286 & 2.64 & Homogen \\
\hline 2 & $\mathrm{Y}_{\text {atas }} \mathrm{X}_{2}$ & 0.153 & 2.64 & Homogen \\
\hline
\end{tabular}


C. Uji Linieritas

1) Uji Liniearitas Data Animasi

Komputer Dengan Hasil Belajar Inseminasi Buatan

Berdasarkan uji $\mathrm{F}$ menggunakan

SPSS di atas diketahui bahwa nilai signifikasi variabel Hasil belajar inseminasi buatan (Y) berdasarkan variabel Media animasi komputer $\left(\mathrm{X}_{1}\right)$ $=0.063<4.75$, artinya data variabel Hasil belajar inseminasi buatan berdasarkan Media animasi komputer $\left(\mathrm{X}_{1}\right)$ adalah linier.

\section{2) Uji Liniearitas Data Motivasi Belajar Dengan Hasil Belajar Inseminasi Buatan}

Berdasarkan uji $\mathrm{F}$ menggunakan SPSS di atas diketahui bahwa nilai signifikasi variabel Hasil belajar inseminasi buatan (Y) berdasarkan variabel Motivasi belajar $\left(\mathrm{X}_{2}\right)=0.000<$ 4.84 artinya data variabel Hasil belajar inseminasi buatan berdasarkan Motivasi belajar $\left(\mathrm{X}_{1}\right)$ adalah linier.

Tabel 4. Rangkuman Hasil Uji

\begin{tabular}{|c|c|c|c|c|}
\hline No & Variabel & $\begin{array}{c}\mathbf{F} \\
\text { Hitung }\end{array}$ & F Tabel & $\begin{array}{c}\text { Kesimpul } \\
\text { an }\end{array}$ \\
\hline 1 & Y atas $\mathrm{X}_{1}$ & 0.063 & 4.75 & Linier \\
\hline 2 & Y atas $\mathrm{X}_{2}$ & 0.000 & 4.84 & Linier \\
\hline
\end{tabular}

\section{Pengujian Hipotesis}
1) Hubungan Media Animasi Komputer dengan Hasil Belajar Inseminasi Buatan

Hipotesis kesatu yang menyatakan bahwa terdapat hubungan positif antara media animasi komputer dengan Hasil belajar inseminasi buatan diuji dengan analisis regresi sederhana. Perhitungan analisis regresi sederhana diperoleh persamaan regresi $\hat{Y}=13.679$ $+0.092 \mathrm{X}_{1}$ dengan arah koefisien regresi sebesar 0.092 dan konstanta sebesar 13.679.

Berdasarkan hasil pengujian korelasi, menunjukkan terjadi korelasi sebesar 0.542. Hal ini menunjukan terdapat hubungan media animasi computer dengan Hasil belajar inseminasi buatan secara positif dan signifikan.

Berdasarkan hasil pengujian signifikansi (uji t) bahwa $\mathrm{t}_{\text {hitung }}>\mathrm{t}_{\text {tabel }}$ (3.411 > 1,697). Hal ini berarti $\mathrm{H}_{n o l}$ ditolak dan $\mathrm{H}_{1}$ diterima. Hasil ini menyatakan Terdapat hubungan positif dan signifikan antara persepsi peserta diklat tentang media animasi komputer dengan hasil belajar inseminasi buatan di BBPKH Cinagara Bogor.

Koefisien determinan $\mathrm{R}$ Square $\left(\mathrm{r}_{\mathrm{y} 1}^{2}\right)$ sebesar 0.294 yang berarti faktor media animasi komputer $\left(\mathrm{X}_{1}\right)$ berperan atau 
memberikan kontribusi sebesar $29.4 \%$ dengan Hasil belajar inseminasi buatan (Y) sedangkan sisanya $70.6 \%$ Hasil belajar inseminasi buatan dipengaruhi oleh faktor lain.

Tabel 5. Uji Korelasi Parsial $X_{1}$ dengan

\begin{tabular}{|c|c|c|c|}
\hline & & $\begin{array}{c}\text { Animasi } \\
\text { Komputer }\end{array}$ & $\begin{array}{c}\text { Hasil } \\
\text { Belajar IB }\end{array}$ \\
\hline \multirow[t]{3}{*}{$\begin{array}{l}\text { Animasi } \\
\text { Komputer }\end{array}$} & $\begin{array}{l}\text { Pearson } \\
\text { Correlation }\end{array}$ & 1 & $.542^{* *}$ \\
\hline & Sig. (2-tailed) & & .002 \\
\hline & $\mathrm{N}$ & 30 & 30 \\
\hline \multirow[t]{3}{*}{$\begin{array}{l}\text { Hasil Belajar } \\
\text { IB }\end{array}$} & $\begin{array}{l}\text { Pearson } \\
\text { Correlation }\end{array}$ & $.542^{* *}$ & 1 \\
\hline & Sig. (2-tailed) & .002 & \\
\hline & $\mathrm{N}$ & 30 & 30 \\
\hline
\end{tabular}

\section{2) Hubungan Motivasi dengan} Hasil Belajar IB

Hipotesis kedua yang menyatakan bahwa terdapat terdapat hubungan positif dan signifikan motivasi belajar dengan hasil belajar Inseminasi buatan di BBPKH Cinagara Bogor diuji dengan analisis regresi sederhana. Perhitungan analisis regresi sederhana diperoleh persamaan regresi $\hat{\mathrm{Y}}=5.491+0.195 \mathrm{X}_{2}$ dengan arah koefisien regresi sebesar 0.195 dan konstanta sebesar 5.491

Berdasarkan hasil pengujian korelasi, menunjukkan terjadi korelasi sebesar 0.775. Hal ini menunjukan terdapat hubungan motivasi belajar dengan hasil belajar Inseminasi buatan secara positif dan signifikan.
Berdasarkan hasil pengujian signifikansi (uji $\mathrm{t}$ ) bahwa $\mathrm{t}_{\text {hitung }}>\mathrm{t}_{\text {tabel }}$ (6.492 > 1,697). Hal ini berarti $H_{\text {nol }}$ ditolak dan $\mathrm{H}_{1}$ diterima. Hasil ini menyatakan terdapat hubungan positif dan signifikan antara motivasi belajar dengan hasil belajar Inseminasi buatan di BBPKH Cinagara Bogor.

Koefisien determinan $\mathrm{R}$ Square $\left(\mathrm{r}_{\mathrm{y} 1}^{2}\right)$ sebesar 0.601 yang berarti faktor motivasi belajar $\left(\mathrm{X}_{2}\right)$ berperan atau memberikan kontribusi sebesar $60.1 \%$ dengan Hasil belajar inseminasi buatan (Y) sedangkan sisanya $39.9 \%$ Hasil belajar inseminasi buatan dipengaruhi oleh faktor lain.

Tabel 6. Uji Korelasi Parsial $X_{2}$ dengan

\begin{tabular}{|c|c|c|c|}
\hline & & $\begin{array}{c}\text { Motivasi } \\
\text { Belajar }\end{array}$ & $\begin{array}{c}\text { Hasil } \\
\text { Belajar IB }\end{array}$ \\
\hline \multirow[t]{3}{*}{$\begin{array}{l}\text { Motivasi } \\
\text { Belajar }\end{array}$} & $\begin{array}{l}\text { Pearson } \\
\text { Correlation }\end{array}$ & 1 & $.775^{* *}$ \\
\hline & Sig. (2-tailed) & & .000 \\
\hline & $\mathrm{N}$ & 30 & 30 \\
\hline \multirow[t]{3}{*}{$\begin{array}{l}\text { Hasil Belajar } \\
\text { IB }\end{array}$} & $\begin{array}{l}\text { Pearson } \\
\text { Correlation }\end{array}$ & $.775^{* *}$ & 1 \\
\hline & Sig. (2-tailed) & .000 & \\
\hline & $\mathrm{N}$ & 30 & 30 \\
\hline
\end{tabular}
3)
Hubungan Media Animasi Komputer dan Motivasi Belajar Secara Bersama-Sama dengan Hasil Belajar Inseminasi Buatan
Hipotesis ketiga yang dajukan dalam penelitian ini adalah terdapat hubungan positif Media animasi komputer $\left(\mathrm{X}_{1}\right)$ dan Motivasi belajar 
$\left(\mathrm{X}_{2}\right)$ secara bersama-sama dengan Hasil belajar inseminasi buatan $(\mathrm{Y})$.

Analisis regresi ganda antara Media animasi komputer $\left(\mathrm{X}_{1}\right)$ dan Motivasi belajar $\left(\mathrm{X}_{2}\right)$ secara bersamasama dengan Hasil belajar inseminasi buatan (Y). memiliki persamaan regresi $=5.464+0.008 X_{1}+0.800 X_{2}$ dengan arah koefisien regresi a 1 sebesar 0.032 , a2 sebesar 0. .204 dan konstanta sebesar 5.464

Berdasarkan hasil uji keberartian persamaan linier ganda diperoleh $F_{\text {hitung }}$ sebesar 0.000 sedangkan $F_{\text {tabel }}$ untuk penyebut 2 dan pembilang 27 untuk taraf kepercayaan a $=0,05$ sebesar 3.35 yang berarti nilai $F_{\text {hitung }}<\mathrm{F}_{\text {tabel }}(0.000<$ 3.35). Hal tersebut menunjukkan bahwa persamaan regresi linier dan signifikan.

Selanjutnya hasil pengujian signifikansi (uji t) bahwa $\mathrm{t}_{\text {hitung }}>\mathrm{t}_{\text {tabel }}$ (2.159 > 1,697). Hal ini berarti $\mathrm{H}_{\text {nol }}$ ditolak dan $\mathrm{H}_{1}$ diterima. Hasil ini menyatakan terdapat hubungan positif antara Media animasi komputer $\left(\mathrm{X}_{1}\right)$ dan Motivasi belajar $\left(\mathrm{X}_{2}\right)$ secara bersama-sama dengan Hasil belajar inseminasi buatan (Y)di BBPKH Cinagara Bogor

Hubungan antara variabel Media animasi komputer $\left(\mathrm{X}_{1}\right)$ dan Motivasi belajar $\left(\mathrm{X}_{2}\right)$ secara bersama-sama dengan Hasil belajar inseminasi buatan (Y), diperoleh $\mathrm{r}_{\mathrm{y} 1.2}$ sebesar $0.776^{\mathrm{a}}$ yang berarti Media animasi komputer $\left(\mathrm{X}_{1}\right)$ dan Motivasi belajar $\left(\mathrm{X}_{2}\right)$ secara bersama-sama dengan Hasil belajar inseminasi buatan (Y) termasuk dalam ketegori kuat.

Nilai koefisien determinan $\left(\mathrm{r}^{2} \mathrm{y} .12\right)$ sebesar 0.602 yang berarti faktor Media animasi komputer $\left(\mathrm{X}_{1}\right)$ dan Motivasi belajar $\left(\mathrm{X}_{2}\right)$ secara bersama-sama berperan/memberikan kontribusi sebesar $60.2 \%$. Sisanya $39.8 \%$ Hasil belajar inseminasi buatan dipengaruhi oleh faktor lain (Y).

Tabel 7. Uji Korelasi Ganda $X_{1}, X_{2}$ dan

\begin{tabular}{|c|c|c|c|c|}
\hline & & $\begin{array}{c}\text { Animasi } \\
\text { Komputer }\end{array}$ & $\begin{array}{c}\text { Motivasi } \\
\text { Belajar }\end{array}$ & $\begin{array}{c}\text { Hasil } \\
\text { Belajar IB }\end{array}$ \\
\hline \multirow[t]{3}{*}{$\begin{array}{l}\text { Animasi } \\
\text { Komputer }\end{array}$} & $\begin{array}{l}\text { Pearson } \\
\text { Correlation }\end{array}$ & 1 & $.729^{* * *}$ & $.542^{* * *}$ \\
\hline & Sig. (2-tailed) & & .000 & .002 \\
\hline & $\mathrm{N}$ & 30 & 30 & 30 \\
\hline \multirow[t]{3}{*}{$\begin{array}{l}\text { Motivasi } \\
\text { Belajar }\end{array}$} & $\begin{array}{l}\text { Pearson } \\
\text { Correlation }\end{array}$ & $.729^{* *}$ & 1 & $.775^{* *}$ \\
\hline & Sig. (2-tailed) & .000 & & .000 \\
\hline & $\mathrm{N}$ & 30 & 30 & 30 \\
\hline \multirow[t]{3}{*}{$\begin{array}{l}\text { Hasil } \\
\text { Belajar IB }\end{array}$} & $\begin{array}{l}\text { Pearson } \\
\text { Correlation }\end{array}$ & $.542^{* *}$ & $.775^{* *}$ & 1 \\
\hline & Sig. (2-tailed) & .002 & .000 & \\
\hline & $\mathrm{N}$ & 30 & 30 & 30 \\
\hline
\end{tabular}

\section{SIMPULAN}

Dari hasil penelitian didapatkan kesimpulan berikut:

a. Terdapat hubungan positif dan signifikan antara persepsi peserta diklat tentang media animasi komputer dengan hasil belajar 
inseminasi buatan di BBPKH

Cinagara Bogor. Koefisien

determinan $\mathrm{R}$ Square (r2y1)

sebesar 0.294 yang berarti faktor

media animasi komputer (X1)

berperan atau memberikan

kontribusi sebesar $29.4 \%$ dengan

Hasil belajar inseminasi buatan

(Y) sedangkan sisanya $70.6 \%$

Hasil belajar inseminasi buatan

dipengaruhi oleh faktor lain.

b. Terdapat hubungan positif dan signifikan motivasi belajar dengan hasil belajar Inseminasi buatan di BBPKH Cinagara Bogor teruji kebenaranya. Koefisien determinan R Square (r2y1) sebesar 0.601 yang berarti faktor motivasi belajar (X2) berperan atau memberikan kontribusi sebesar $60.1 \%$ dengan Hasil belajar inseminasi buatan (Y) sedangkan sisanya $39.9 \%$ Hasil belajar inseminasi buatan dipengaruhi oleh faktor lain.

c. Terdapat hubungan positif dan signifikan antara persepsi peserta diklat tentang media animasi komputer dan motivasi belajar secara bersama-sama dengan hasil belajar Inseminasi buatan di BBPKH Cinagara Bogor. Nilai koefisien determinan (r2y.12) sebesar 0.602 yang berarti faktor Media animasi komputer (X1) dan Motivasi belajar (X2) secara bersama-sama berperan/ memberikan kontribusi sebesar 60.2\%. Sisanya $39.8 \%$ Hasil belajar inseminasi buatan dipengaruhi oleh faktor lain (Y).

\section{DAFTAR PUSTAKA}

Anik Widiastuti. (2007). Studi Eksplorasi tentang Motivasi MahaPeserta Diklat Pendidikan Ekonomi FISE UNY. Yogyakarta

Anonimous. (2005). Budidaya Ternak Sapi Potong Menrsitek.

Arsyad, Azhar, (2007). Media Pembelajaran. Jakarta: Raja Grafindo Persada.

Demita, N. (2011). Adopsi Inovasi Inseminasi Buatan pada Peternak Sapi Potong di Kecamatan Kuranji. Skripsi. Fakultas Peternakan Universitas Andalas. Padang

Dewi Salma Prawiradilaga dan Evelinesiregar, (2004) Mozaik Teknologi Pendidikan, Jakarta: Prenada Media.

Djamarah, Syaiful Bahri. (2011). Psikologi Belajar. Jakarta. Rineka Cipta,

Hafez, E. S. E. (1993). Artificial insemination. In: HAFEZ, E.S.E. 1993. Reproduction in Farm Animals. 
Harjanto. (2008). Perencanaan Pengajaran. Jakarta: Rineka Cipta.

Hunter, R. H. F. (1981). Fisiologi dan Teknologi Reproduksi Hewan Betina Domestik. Universitas Usaya. Bandung.

Husaini, Fauziah T. (2009). Pengaruh Penggunaan Media Pembelajaran Terhadap Hasil Belajar Peserta diklat di SMP Negeri 1 Kabila. Skripsi. Perpustakaan Pusat UNG. Gorontalo.

Mardikanto, T. (1993). Penyuluhan Pembangunan Pertanian. Universitas Negeri Sebelas Maret Surakarta Press. Surakarta.

Martin Handoko. (1992). Motivasi Daya Penggerak Tingkah Laku. Jakarta: PT Rineka Cipta,

Martinis Yamin, (2007) Kiat Membelajarkan Peserta didik, Jakarta: Gaung Persada Press.

Murtidjo, B.A. (2000). Berternak sapi potong. Kanisius.Yogyakarta.

Nana Syaodih Sukmadinata. (2003). Landasan Psikologi Proses Pendidikan. Bandung: PT Remaja Rosdakarya.

Nasution. (1999). Teknologi Pendidikan. Jakarta: PT Bumi Aksara.

Ngalim M, Purwanto. (2007). Psikologi Pendidikan. Bandung: PT Remaja Rosdakarya,

Oemar Hamalik. (2001). Psikologi Belajar dan Mengajar.Bandung: Sinar Baru Bandung
Partodihardjo, S. (1992). Ilmu Reproduksi Hewan. Cetakan ke-3 Penerbit Mutiara Sumber Widia, Jakarta.

Pateda, S. Y. (2010). Tingkat adopsi petani terhadap teknologi inseminasi buatan pada sapi di Kecamatan Paguyaman. Fakultas Ilmu-Ilmu Pertanian. Universitas Negeri Gorontalo. Saintek.

Rasyaf, M. (1996). Memasarkan Hasil Peternakan. Penebar Swadaya. Jakarta.

Rauf, Elina A. (2010). Hubungan Antara Media Pembelajaran Dengan Motivasi Belajar Peserta diklat Di SMA Mohammadiyah Batuda'a. Skripsi. Perpustakaan Pusat UNG. Gorontalo.

Rumini, Sri, dkk. (1995). Psikologi Pendidikan.Yogyakarta: UPP IKIP Yogyakarta.

Sadiman, Arief S, (2009). Media Pendidikan - Pengertian, Pengembangan, dan Pemanfaatannya. Jakarta: PT Raja Grafindo Persada.

Sadirman. (2004). Interaksi dan Motivasi Belajar Mengajar. Penerbit CV. Grafindo. Jakarta.

Sagala, Syaiful. (2012). Konsep dan Makna Pembelajaran. Bandung: Alfabeta

Salisbury, G.W, dan Vandemark. MIL, (1985). Fisiologi dan Inseminasi Buatan Pada Sapi. (diterjemahkan oleh R. Djanuar). UGM press. Yogyakarta.

Sanjaya, Wina. (2009). Strategi Pembelajaran Berorientasi 
Standar Proses Pendidikan. Yusufhadi Miarso (2005), Menyemai Jakarta: Kencana, Benih Teknologi Pendidikan, Jakarta: Kencana.

Sardiman AM. (2009) Interaksi dan Motivasi Belajar Mengajar. Jakarta: Raja Grafindo Persada.

Sugeng, Y. B. (1997). Sapi Potong. Penerbit CV. Yasa Guna. Jakarta.

Sugeng, Y.B. (2002). Sapi Potong. Swadaya. Jakarta.

Sukmadinata, Syaodih. (2009). Landasan Psikologi Proses Pendidikan.Bandung: Remaja Rosdakarya,

Sumoprastowo. (2003). Penggemukan Sapi dan Kerbau. Bhrata. Jakarta.

Suryabrata, Sumadi. (2006). Psikologi Pendidikan. Jakarta: PT Grafindo Persada.

Susanto, Ahmad. (2013). Teori Belajar dan Pembelajaran di Sekolah Dasar. Jakarta: Kencana Prenada Media Group.

Tabrany. H. (2004). Pengaruh proses pelayuan terhadap keempukan daging Herman tabrany@yahoo.co.id.

Toelihere, M. R. (1993). Inseminasi Buatan pada ternak. Angkasa Bandung. GW Salisbury N.I. Vandermark Diterjemahkan oleh. Prof. Drh. R. Djanuar.1995. Fisiolgi Reproduksi dan Inseminasi Buatan pada ternak.

Uno, Hamzah B. (2011). Profesi Kependidikan - Problema, Solusi, dan Reformasi Pendidikan di Indonesia. Jakarta: PT Bumi Aksara.

http://kbbi.web.id/ajar

http://kbbi.web.id/animasi

http://marcoturnip.blog.widyatama.ac.i $\mathrm{d} / 2014 / 06 / 14 /$ pengertian-prinsipprinsip-dan-perbedaan-animasi

http://tittiduit.blogspot.co.id

kbbi.web.id/motivasi

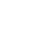

